\title{
Kontaminasi Logam Berat As dan Hg pada Airtanah Dangkal di Wilayah Pesisir Semarang dan Demak
}

\author{
Baskoro Rochaddi*, Agus Sabdono² dan Muhammad Zainuri \\ 'Departemen Oseanografi, Fakultas Perikanan dan Ilmu Kelautan, Universitas Diponegoro \\ 2Departemen IImu Kelautan, Fakultas Perikanan dan IImu Kelautan, Universitas Diponegoro \\ JI. Prof. Soedarto, SH. Kampus UNDIP Tembalang, Semarang 50275 \\ Email: brochaddi@gmail.com
}

\begin{abstract}
As and $\mathrm{Hg}$ Contamination in Shallow Groundwater in the Coastal Areas of Semarang and Demak

The present study was performed to assess the level of heavy metal contamination in shallow groundwater of Semarang and Demak coastal areas. Groundwater sample analysis indicated that Mercury and Arsenic were detected in the groundwater samples in the range $0.023-0.266 \mu \mathrm{g} / \mathrm{L}$ and $0.102-0.505 \mathrm{\mu g} / \mathrm{L}$, respectively. Compared to the standard limits of the heavy metals contents in the water sample by World Health Organization (WHO) limits and Indonesian Drinking and Domestic Water Quality Standard for Ground Water (IWQS), groundwater of Semarang and Demak Coastal Areas was contaminated with heavy metals. This study has confirmed the presence of heavy metal contamination of some shallow groundwater supplies in the coastal areas of Semarang and Demak.
\end{abstract}

Keywords: Contamination, heavy metal, shallow groundwater

\begin{abstract}
Abstrak
Penelitian ini dilakukan untuk menilai tingkat kontaminasi logam berat di air tanah dangkal di wilayah pantai Semarang dan Demak. Analisis sampel air tanah menunjukkan bahwa Merkuri dan Arsen terdeteksi dalam sampel air tanah dalam kisaran 0.023-0.266 $\mu \mathrm{g} / \mathrm{L}$ dan 0.102-0.505 $\mathrm{\mu g} / \mathrm{L}$, masing-masing. Dibandingkan dengan batas standar konsentrasi logam berat dalam sampel air oleh batas Organisasi Kesehatan Dunia (WHO) dan Standar Kualitas Air Minum dan Domestik Indonesia untuk Air Tanah (IWQS), air tanah Wilayah Semarang dan Demak telah terkontaminasi dengan logam berat. Studi ini telah mengkonfirmasi adanya kontaminasi logam berat dari beberapa pasokan air tanah dangkal di wilayah pesisir Semarang dan Demak.
\end{abstract}

Kata kunci : Kontaminasi, Logam Berat, Airtanah dangkal

\section{PENDAHULUAN}

Indonesia memiliki kurang lebih 12.827 desa yang terletak di wilayah pesisir, desadesa tersebut mengambil air bersih dari berbagai sumber, termasuk air kemasan (1.106 desa), air tadah hujan (1.002 desa), mata air (2.761 desa), sumur (4.703 desa), sungai / kolam (374 desa), dan PAM (1.330) (Ambari, 2018). Mata air dan sumur ini bersumber dari air tanah atau dengan kata lain, masih ada $7.464(58,1 \%)$ desa pesisir di
Indonesia yang mengandalkan air tanah sebagai sumber air minum. Airtanah adalah air yang terdapat di bawah permukaan tanah yang terbentuk di bawah muka airtanah, di dalam soil atau formasi geologi yang merupakan zona jenuh (Freeze dan Cherry, 1979). Air adalah pelarut yang sangat baik sehingga dapat mengandung banyak bahan kimia yang terlarut. Karena air tanah bergerak melalui bebatuan dan tanah bawah permukaan, airtanah memiliki banyak waktu untuk melarutkan zat selama mengalir. 
Oleh karena itu, air tanah seringkali memiliki lebih banyak zat terlarut daripada air permukaan.

Masalah pertama adalah bagaimana kondisi air tanah dangkal di pantai utara Jawa, apakah masih bagus atau sudah terkontaminasi oleh logam berat atau polutan lainnya karena kegiatan pertanian atau industri di daerah hulu. Dari hasil penelitian Pusat Penelitian dan Pengembangan Provinsi Jawa Tengah tahun 2004, menunjukkan bahwa di 12 kabupaten / kota di pantai utara Jawa Tengah sudah mengandung logam berat $(\mathrm{Hg}, \mathrm{Cd}, \mathrm{Co}, \mathrm{Pb}$, $\mathrm{Cr}, \mathrm{Ni}, \mathrm{Zn}$, dan As) dalam air, endapan dan cangkang jaringan lunak, konsentrasi logam berat ini sebagian besar telah melebihi ambang batas standar kualitas yang ditetapkan oleh Keputusan Menteri Lingkungan Hidup No. 51 tahun 2004 (Suyanto et al., 2010). Semarang sebagai bagian dari daratan dan air pantai Jawa Utara telah terkontaminasi oleh logam berat. Logam berat antropogenik telah ditemukan di perairan pantai dan daratan di bagian barat Semarang [Suryono, 2016]. Selanjutnya, ditemukan beberapa logam berat dalam sedimen laut seperti $\mathrm{Cr}, \mathrm{Pb}$, dan $\mathrm{Cu}$. Rochaddi et al. (2018) menemukan bahwa beberapa lokasi airtanah dangkal di wilayah pesisir Semarang telah tercemar oleh logam berat Arsen dan pestisida (heptaklor). Penelitian Purba dan Kamil (2015) tentang penyebaran logam berat pada airtanah dangkal akibat lindi di sekitar Tempat Pemrosesan Akhir Jatibarang Semarang, menyimpulkan bahwa konsentrasi kromium hexavalen dan timbal pada lindi TPA Jatibarang telah melebihi standar baku mutu yang ditetapkan. Konsentrasi kontaminan pada air tanah yang digunakan oleh warga pada parameter kromium hexavalent telah berada pada masa rentan pada standar baku mutu, yaitu 0,0135-0,045 mg/l.

Penelitian sebelumnya membuktikan bahwa pesisir Semarang sudah terkontaminasi oleh logam berat pada air laut dan sedimen. Logam-logam berat dalam air dan sedimen di sana diprediksi berasal dari luar maupun dari dalam air pantai Semarang. Wilayah pesisir Semarang telah dikelilingi oleh banyak sungai seperti sungai Semarang, Sungai Kanal Banjir Barat, Sungai Kanal Banjir Timur, sungai Babon dan sungai Banger. Sedangkan logam berat yang berasal dari dalam air pantai diasumsikan berasal dari korosi logam kapal dan bangunan.

Arsen dan merkuri adalah logam berat yang sangat beracun. Beberapa penelitian telah menunjukkan bahwa beberapa sumber air bersih telah terkontaminasi dengan logam berat. Keberadaan air tanah di wilayah pesisir merupakan sumber air bersih yang penting, sehingga perlu dipelajari keberadaan arsen dan merkuri dalam air tanah di wilayah pesisir. Studi tentang kontaminasi arsen dan merkuri dalam air tanah di daerah pantai Semarang dan Demak masih sangat sedikit atau tidak banyak diketahui, sehingga perlu untuk mempelajari keberadaan logam berat dalam air tanah di daerah Semarang dan Demak ini.

\section{MATERI DAN METODE}

Pengambilan sampel air tanah: Titik pengambilan sampel airtanah terletak di daerah pesisir Semarang dan Demak. Arah aliran airtanah relatif mengalir dari bagian selatan ke bagian utara. Gambar 1 menunjukkan lokasi pengambilan sampel dari 8 sumur dangkal/gali yang berbeda di kotakota tersebut (Semarang: SUA 01, SUA 02, STA 02, MK 01 dan MK 03; Demak: DSA 01, DMA 01, dan DBA 01); sampel air tanah dikumpulkan dalam botol plastik polietilen dari berbagai daerah di sepanjang daratan pesisir.

Sampel dikumpulkan dalam botol plastik 5 liter. Kemudian, botol diberi label dengan benar dan ditutup rapat. Semua sampel dibawa ke laboratorium untuk dilakukan analisis Logam Berat (Arsen dan Merkuri). Parameter yang dianalisis adalah sifat psiko-hidrokimia dan konsentrasi Logam Berat air tanah dangkal. $\mathrm{PH}$, salinitas, dan suhu diukur pada saat pengambilan sampel menggunakan $\mathrm{pH}$ meter, salino-refraktometer portable dan termometer Celcius standar (Horiba Co. Ltd., Jepang). Prosedur analitik Arsen dan Merkuri yang digunakan adalah metode Metode Standar untuk Pemeriksaan Air dan Air Limbah (Federation, 2005). Sampel air kemudian dianalisis oleh Inductively Coupled Plasma (ICP). 


\section{HASIL DAN PEMBAHASAN}

Wilayah pantai Semarang dan Demak secara administratif dibagi menjadi dua wilayah (Semarang berada di bagian barat dan Demak di bagian timur). Kota ini dipilih untuk studi karena keterwakilan Semarang sebagai kota industri dan Demak sebagai kota pertanian serta sebagian industri. Oleh karena itu, kota-kota tersebut memiliki kemungkinan besar akan daya dukung kualitas sumber daya air yang menurun.
Dalam penelitian ini, hasil dari beberapa parameter fisikokimia Logam Berat (Arsen dan Merkuri) yang dipilih di Akifer Air Tanah Dangkal di wilayah pesisir Semarang dan Demak masing-masing ditunjukkan dalam Tabel 1.

Studi ini menunjukkan bahwa variasi rendah ada di antara beberapa parameter fisikokimia (suhu, salinitas, pH). Warna, rasa, dan bau terdeteksi dalam sampel air. Beberapa sampel air, terutama beberapa sampel air, tidak memenuhi batas standar

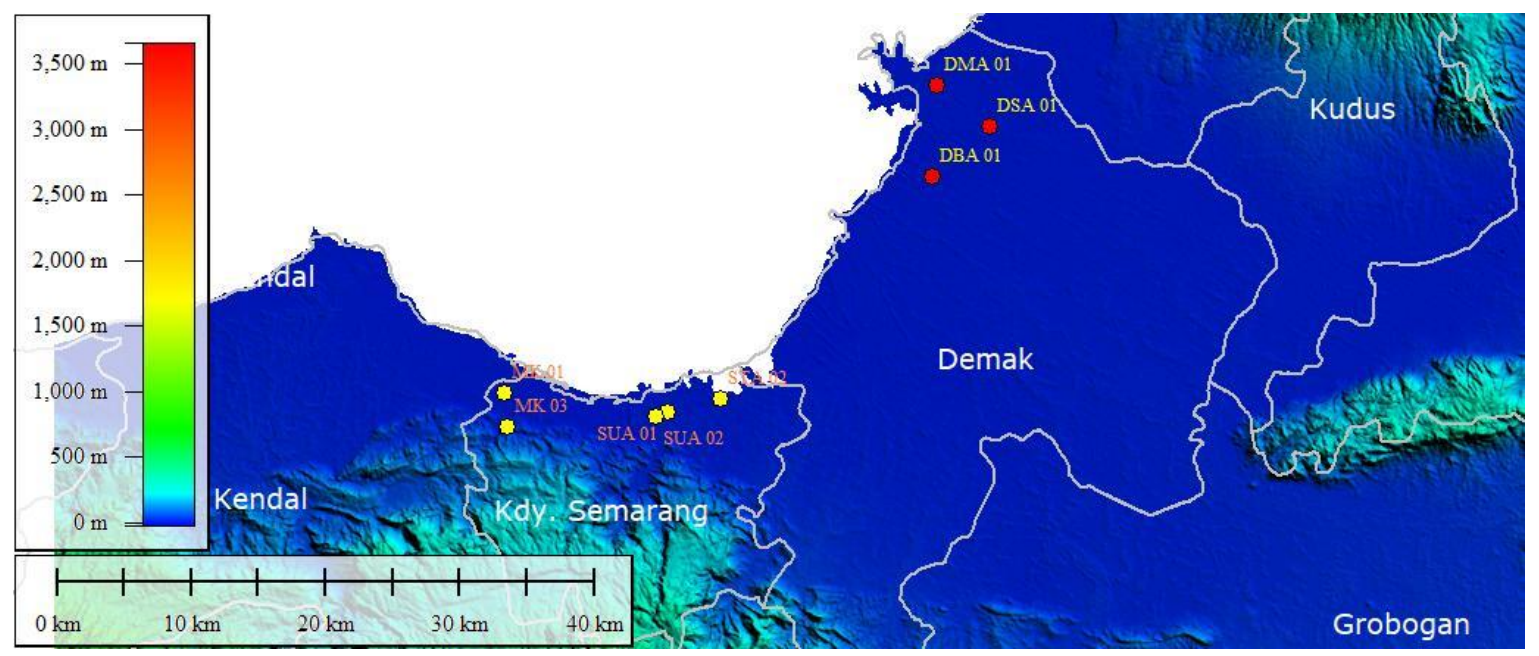

Gambar 1. Lokasi sampel airtanah dangkal di Semarang dan Demak

Tabel 1. Konsentrasi Logam Berat pada airtanah dangkal di Semarang dan Demak

\begin{tabular}{cccc}
\hline Semarang - Demak (Kode Area) & Logam Berat & Konsentrasi (ppm) & SD \\
\hline SUA 01 & As & 0.102 & 0.2055 \\
SUA 02 & Hg & 0 & 0 \\
& As & 0.366 & 0.0956 \\
STA 02 & Hg & 0 & 0 \\
& As & 0.267 & 0.1562 \\
MK 01 & Hg & 0.266 & 0.4533 \\
& As & 0.219 & 0.1745 \\
MK 03 & Hg & 0.023 & 0.2104 \\
& As & 0.156 & 0.1610 \\
DSA 01 & Hg & 0 & 0 \\
& As & 0.505 & 0.1478 \\
DMA 01 & Hg & 0 & 0 \\
& As & 0.246 & 0.1706 \\
DBA 01 & As & 0.053 & 0.0956 \\
& Hg & 0.213 & 0.1255 \\
\hline
\end{tabular}


untuk minum. Beberapa sampel air memiliki warna dan bau yang tidak enak. Nilai suhu air yang diperoleh dalam penelitian ini bervariasi sedikit berkisar antara $28-29^{\circ} \mathrm{C}$ dengan rata-rata $28.667^{\circ} \mathrm{C}$. Ini adalah suhu air yang paling umum di zona tropis. Rentang suhu sampel air ini diduga dipengaruhi oleh intensitas sinar matahari karena suhu naik dari $28,5-29,5^{\circ} \mathrm{C}$ pada siang hari yang relatif panas. Beberapa pekerja melaporkan bahwa suhu air dari iklim tropis sedikit dipengaruhi oleh variasi suhu musiman (Efe et al., 2005). Kisaran salinitas bervariasi dari 0 hingga $5,0 \%$ dengan rata-rata $0,8333 \pm 2,04 \%$ 0 . Level tertinggi yang diinginkan untuk $\mathrm{pH}$ $(7,0)$ berada dalam kisaran nilai 6,5-8,0 untuk keperluan minum (WHO, 2004). Untuk menganalisis keberadaan logam berat dalam air tanah lebih jelas, hasil analisis lokasi di Semarang dan Demak dipisahkan.

Secara alami, keberadaan logam arsen dapat ditemukan di tanah, udara, sedimen, dan tanaman. Arsen terlarutkan dalam air dalam bentuk senyawa organik dan anorganik. Beberapa penelitian di Amerika dan Eropa menunjukkan bahwa konsentrasi arsen dalam air secara alami dalam kondisi yang tidak tercemar adalah di bawah 0,01 ppm. Tingginya konsentrasi arsen dalam air biasanya hingga 8,5 ppm ditemukan di lokasi di mana terdapat aktivitas panas bumi (geothermal). Kehadiran metaloid arsen dengan konsentrasi tinggi dalam air tanah dapat dikaitkan dengan deposit bijih di mana Arsen dijumpai terutama dalam mineral sulfida seperti arsenopirit dan pirit (Shankar dan Shanker, 2014).. Arsenopyrite (FeAsS) adalah mineral yang mengandung As paling banyak yang umumnya ada di lingkungan anaerob dan di berbagai mineral pembentuk batuan lainnya seperti sulfida, oksida, fosfat, karbonat, dan silikat,

Konsentrasi arsen di lokasi penelitian berkisar antara 0,102-0,505 ppm jauh di atas nilai alami 0,01 ppm; sedangkan daerah penelitian bukan merupakan wilayah panas bumi, yang menunjukkan bahwa air tanah dangkal telah tercemar. Berdasarkan lokasi area penelitian, Semarang dan Demak adalah kota industri dan pertanian, sehingga dapat diartikan bahwa sumber utama polutan arsen berasal dari kegiatan pertanian dan industri. Arsen tersebut adalah bahan metaloid yang terkenal beracun dan memiliki tiga bentuk alotropik; kuning, hitam, dan abu-abu. Penelitian Wongsasuluk et al., (2018) menggunakan rambut dan kuku untuk bio-monitoring logam berat / metaloid dalam air tanah di daerah pertanian intensif di Thailand, penelitian menemukan Konsentrasi As dan logam berat $\mathrm{Cd}, \mathrm{Pb}$ dan $\mathrm{Hg}$ secara signifikan lebih tinggi pada sampel kuku dan rambut masyarakat setempat sering mengonsumsi air tanah dangkal yang terkontaminasi As dan logam berat dibandingkan dengan yang mengonsumsi air keran. Arsen dan senyawa arsen didalam sektor pertanian digunakan sebagai pestisida, herbisida, insektisida, dan dalam berbagai industri logam/aloy. Hasil analisis

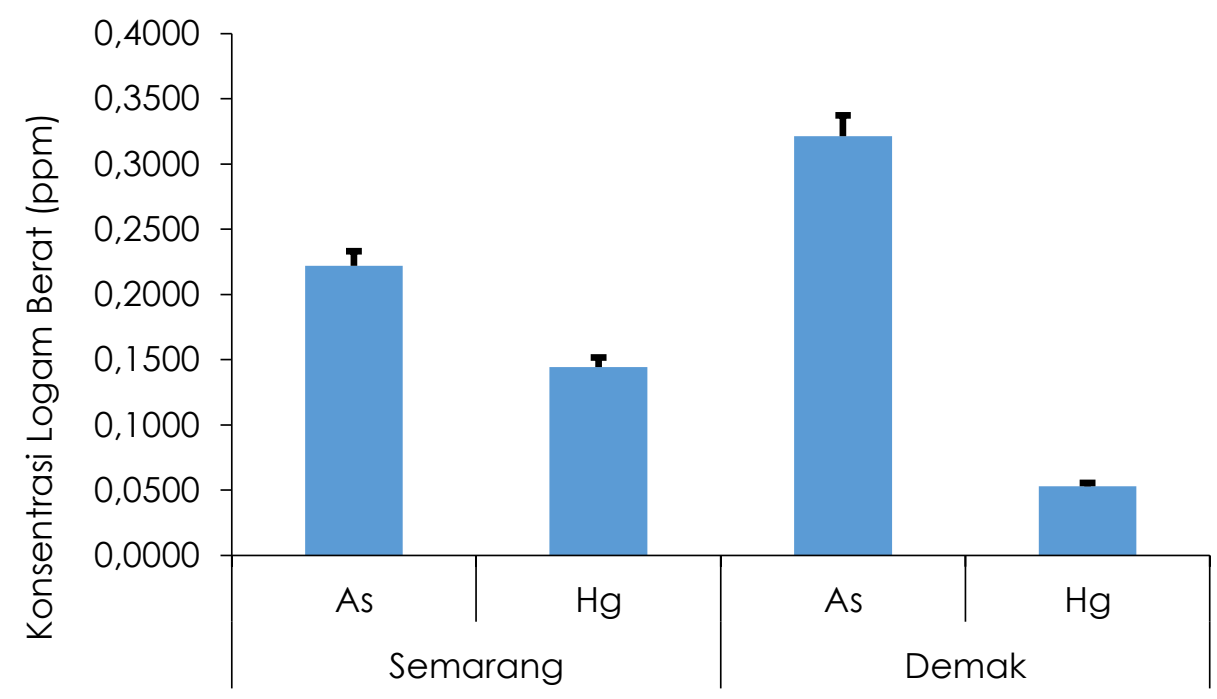

Gambar 2. Konsentrasi logam berat pada airtanah dangkal Semarang dan Demak 
arsen menunjukkan bahwa konsentrasi arsen dalam air tanah di Demak lebih tinggi daripada di Semarang. Pola penggunaan lahan di kedua daerah berbeda dimana Demak penggunaan lahan utama adalah pertanian dan sebagian industri sedangkan Kota Semarang lebih utama industri dan pemukiman. Dapat disimpulkan bahwa konsentrasi arsen dalam air tanah adalah karena kegiatan pertanian dan industri.

Hasil analisis merkuri dari 8 lokasi sampel air tanah di Semarang dan Demak menunjukkan bahwa hanya tiga lokasi yang mengandung merkuri dapat dideteksi. Merkuri dianggap logam berbahaya karena sebagai ion atau dalam bentuk senyawa tertentu, ia mudah diserap ke dalam tubuh. Di dalam tubuh, merkuri dapat menghambat fungsi berbagai enzim dan bahkan dapat menyebabkan kerusakan sel. Kehadiran logam berat $\mathrm{Hg}$ di lingkungan dapat terjadi melalui aktivitas vulkanik, pelapukan batuan, dan sebagai akibat dari aktivitas manusia. Namun, pencemaran merkuri di perairan laut lebih disebabkan oleh faktor manusia daripada faktor alam. Mayoritas merkuri di lingkungan berasal dari kegiatan antropogenik, seperti penambangan, pembakaran bahan bakar fosil, pabrik pengolahan kertas, emisi smelter, dll. Di lingkungan, merkuri yang terkandung dalam limbah di perairan umum dikonversi oleh aktivitas mikroorganisme menjadi komponen dari metil merkuri (senyawa organik) oleh mikroorganisme. Kontaminasi $\mathrm{Hg}$ pada air tanah dari sumber industri ditemukan di banyak negara di mana, secara umum, kontaminasi tersebut relatif lokal. Industri kloralkali yang pernah menghasilkan gas klorin dan natrium hidroksida menggunakan teknologi sel $\mathrm{Hg}$ telah terbukti berkontribusi polutani $\mathrm{Hg}$ pada air permukaan, tanah dan air tanah (Barringer dan Reilly, 2013).

Merkuri terdeteksi dalam airtanah di Semarang pada STA 02 dan MK 01 dan di Demak pada DMA 01 . Lokasi STA 02 dalam Kawasan Terboyo dan MK 01 dalam Kawasan Mangkang Semarang merupakan kawasan industri. Salah satu pemanfaatan lahan pada Terboyo merupakan Kawasan industri dengan basis kegiatan industri garmen, perakitan kendaraan bermotor, kimia, kayu, karet dan plastik, industri Logam Dasar, Barang Logam, Mesin dan Elektronik dan lain- lain (DPMPTSP Provinsi Jawa Tengah, 2019). Pemanfaatan lahan di daerah Mangkang juga cukup banyak dimanfaatkan sebagai Kawasan industri. Secara formal tercatat dua Kawasan industri besar di daerah tersebut serta cukup banyak kegiatan home industri dengan jenis kegiatan industri yang beragam. Airtanah Demak, pada lokasi DMA 01 yang terletak pada Kawasan Menco, Kecamatan Wedung secara umum di bagian atas (hulu) lokasi sampel merupakan lahan pertanian dan di sekitarnya pemukiman yang cukup padat dengan usaha perikanan.

Dijumpainya merkuri pada airtanah dangkal di Semarang kemungkinan paling besar berasal dari limbah kegiatan industri (pabrik kertas, industri lampu, peralatan listrik, kosmetik dan pertanian/ fungisida dIII). Kehadiran merkuri dalam air tanah di sumur dangkal di Demak di daerah pemukiman kemungkinan terjadi dari aktivitas industri pertanian (fungisida) atau aktivitas manusia yang secara sembarangan membuang limbah yang mengandung merkuri sehingga akhirnya merembes ke aliran air tanah dangkal. Konsentrasi merkuri di Semarang secara umum dijumpai lebih tinggi dibanding konsentrasi merkuri di Demak, hal ini dapat diinterpretasikan jumlah polutan yang lebih besar berasal dari kawasan industri atau juga dapat dihubungkan dengan jarak sumber polutan (kegiatan industry) yang lebih dekat dengan lokasi pengambilan sampel. Hal tersebut sesuai dengan hasil penelitian Boky et al. (2015) yang memperoleh hasil terdapat hubungan antara nilai konsentrasi dengan jarak sumber polutan (wilayah pertambangan). Hasil tersebut juga mirip dengan hasil penelitian Rochaddi et al. (2019) yang memperoleh korelasi negative antara konsentrasi pestisida klorpirifos pada airtanah dangkal dengan jarak sumber pencemar (wilayah pertanian) di Surabaya dan Sidoarjo.

\section{KESIMPULAN}

Arsen dan mercury ditemukan dalam sampel air tanah dangkal di Semarang dan Demak dengan berbagai tingkat konsentrasi. Analisis sampel air tanah menunjukkan bahwa Merkuri dan Arsen terdeteksi dalam kisaran 0.023-0.266 $\mu \mathrm{g} / \mathrm{L}$ dan 0.102-0.505 $\mu \mathrm{g} / \mathrm{L}$. Secara umum rata-rata konsentrasi Arsen di Demak lebih tinggi dibandingkan di 
Semarang sedangkan konsentrasi mercury di Demak lebih rendah dibandingkan Semarang. Konsentrasi arsen dan mercury yang jauh di atas konsentrasi alami air ratarata di Indonesia menunjukkan bahwa air tanah di daerah penelitian telah tercemar oleh arsen dan mercury. Kemungkinan terbesar sumber utama polutan arsen dan mercury adalah kegiatan pertanian dan industri di kota Semarang dan Demak.

\section{UCAPAN TERIMA KASIH}

Artikel ini merupakan bagian dari penelitian Disertasi S3 program Doktor IImu Kelautan Fakultas Perikanan dan IImu Kelautan Universitas Diponegoro, Semarang.

\section{DAFTAR PUSTAKA}

Ambari. 2018. Indonesia Negeri Tropis, Tapi Krisis Air Bersih di Kawasan Pesisir Terjadi? Mongabay. Situs berita lingkungan. http://www.mongabay.co.id/2018/ 03/23/indonesia-negeri-tropis-tapi-krisisair-bersih-di-kawasan-pesisir-terjadi/

Barringer, J.L. \& Reilly, P.A., 2013. Occurrence and Mobility of Mercury in Groundwater. In Current Perspectives in Contaminant Hydrology and Water Resources Sustainability chapter 5 . IntechOpen. doi : $10.5772 / 55487$.

Boky, H., Umboh, J.M. \& Ratag, B. 2015. Perbedaan Kandungan Merkuri (Hg) Air Sumur Gali Berdasarkan Jarak dari Sumber Pencemar di Wilayah Pertambangan Rakyat Desa Tatelu I. J. IImu Kesehatan Masyarakat Unsrat. 5(1): 63-70.

Efe, S.I., Ogban, F.E., Horsfall, M.J. \& Akporhonor, E.E. 2005. Seasonal variations of physico-chemical characteristics in water resources quality in western Niger Delta region, Nigeria. J. Appl. Sci. Environ. Manag., 9(1):191-5.

Federation, W.E. \& American Public Health Association, 2005. Standard methods for the examination of water and wastewater. American Public Health Association (APHA): Washington, DC, USA.
Freeze, R.A. \& J.A. Cherry. 1979. Groundwater. Prentice Hall, Inc. USA.

Purba, D.C.V. and Kamil, I.M., 2015. Analisis Pola Penyebaran Logam Berat Pada Air Tanah Dangkal Akibat Lindi Di Sekitar Tempat Pemrosesan Akhir (TPA) Jatibarang, Semarang. J. Tek. Lingk., 21 (2):149-158.

Rochaddi, B., Sabdono, A., \& Zainuri, M. 2019. Preliminary study on the contamination of organophosphate pesticide (chlorpyrifos) in shallow coastal groundwater aquifer of Surabaya and Sidoarjo, East Java Indonesia. IOP Conf. Ser. : Earth Environ. Sci. 246:012079

Rochaddi, B., Suryono, C.A., Atmodjo, W. \& Satriadi, A. 2018. Preliminary Study Contamination of Organochlorine Pesticide (Heptachlor) and Heavy Metal (Arsenic) in Shallow Groundwater Aquifer of Semarang Coastal Areas. IOP Conf. Ser. : Earth Environ. Sci. 116:012099 doi : 10.1088/1755-1315/116/1/012099

Shankar, S. \& Shanker, U., 2014. Arsenic contamination of groundwater: a review of sources, prevalence, health risks, and strategies for mitigation. Scientific World J., Article ID 304524, 18 pages. doi : $10.1155 / 2014 / 304524$

Suyanto, A., Kusmiyati, S. and Retnaningsih, C., 2010. Residu Logam Berat Ikan Dari Perairan Tercemar Di Pantai Utara Jawa Tengah. Program Studi Teknologi Pangan Universitas Muhammadiyah Semarang. J. Pangan dan Gizi, 1 (02):33-38.

Suryono, C.A. 2016. Akumulasi Logam Berat $\mathrm{Cr}, \mathrm{Pb}$ dan $\mathrm{Cu}$ dalam Sedimen dan Hubungannya dengan Organisme Dasar di Perairan Tugu Semarang. J. Kel. Trop. 2(19):143-149.

Wongsasuluk, P., Chotpantarat, S., Siriwong, W. \& Robson, M., 2018. Using hair and fingernails in binary logistic regression for bio-monitoring of heavy metals/metalloid in groundwater in intensively agricultural areas, Thailand. Environ. Res., 162:106118.

World Health Organization [WHO]. 2004 Guidelines for drinking-water quality. Vol. 1. World Health Organization; 